\title{
The Seroprevalence Of Hepatitis B And C Virus Co-Infection Among HIV-1-infected Patients In Keffi, North Central Nigeria.
}

\author{
${ }^{1,}{ }^{2}$ Okwori, A.E.J., ${ }^{2}$ Alabi, S.S., ${ }^{2}$ Ngwai, Y.B., ${ }^{2}$ Makut, M.D., ${ }^{2}$ Obiekezie, S.O., \\ ${ }^{2}$ Ishaleku, D., ${ }^{3}$ Gabo, S., ${ }^{4}$ Akogwu, N. G., ${ }^{5}$ Anejo Okopi, J., ${ }^{6}$ Ameh, J., ${ }^{7}$ Adikwu T.I. \\ ${ }^{I}$ Department Of Medical Microbiology, Federal College Of Veterinary And Medical Laboratory Technology, \\ Vom. ${ }^{2}$ Department Of Biological Sciences, Faculty Of Natural And Applied Sciences, Nasarawa State \\ University, Keffi. ${ }^{3}$ Federal Medical Centre, Keffi. ${ }^{4}$ Department Of Medical Microbiology, National Hospital, \\ Abuja, ${ }^{5}$ Aids Prevention And Initiative In Nigeria (APIN), Jos University Teaching Hospital, Jos. ${ }^{6}$ Family \\ Health International, Abuja, FCT, Nigeria, ${ }^{7}$ Royal Infirmary Hospital, Edinburgh, UK.
}

\begin{abstract}
Human Immunodeficiency Virus (HIV), Hepatitis B Virus (HBV), and Hepatitis C Virus (HCV) are devastating disease agents that share common modes of transmission. This study was aimed at determining the prevalence of hepatitis $B$ and $C$ co-infection rates among HIV patients accessing healthcare at Federal Medical Center Keffi, Nasarawa State, Nigeria. This study lasted between June-December, 2012. A total of 200 seropositive HIV patients participated in the study at the ART clinic. Blood samples collected routinely were screened for the presence of $H B V$ and HCV. Socio-demographic information was collected by the use of a questionnaire. The study population comprised of 54(27\%) males and $146(73 \%)$ females. $11 \%(22 / 200)$ were positive for $H B V, 13.5 \%$ (27/200) were positive for $H C V$ and $5 \%(10 / 200)$ were positive for both $H B V$ and $H C V$. The prevalence rates of hepatitis $B$ and $C$ co-infection among the HIV patients was insignificantly different $(P>0.05)$ statistically for sex $(P=0.37)$ and ART status $(P=0.57)$ different for Educational status $(P=0.57)$, Marital status $(P=0.09)$, Age $(P=0.99)$, Occupation $(P=0.79)$, CD4 Count $(P=0.96)$ and sociodemographic factors $(P=0.88)$. The prevalence rates of $H B V$ and $H C V$ co-infection are increasing in patients with HI. Having acquired the knowledge about the importance of such a co-infection, it is essential that all the patients with HIV be screened for HBV and HCV co-infection.
\end{abstract}

Keywords: Serosurvey - Hepatitis/HIV - Co-Infection - Keffi - Nigeria

\section{Introduction}

Human Immunodeficiency Virus (HIV) infection, a worldwide phenomenon is a serious public health problem. HIV infection has globally claimed over 25 million lives, and recent studies have shown that over 40 million people have been infected (UNAIDS, 2005). The rate of infection is remarkably high in sub-Saharan Africa, where the majority of HIV and AIDS cases are concentrated (UNAIDS and WHO, 2002).

Hepatitis B virus (HBV), a DNA virus of the family hepadnaviridae is the causative agent of hepatitis B infection (Punpapong et al., 2007). It is 50-100 times more infectious than HIV and 10 times more infectious than hepatitis $\mathrm{C}$ virus (HCV) with many carriers not realizing that they are infected with the virus, thus it is referred to as a "silent killer"(Samuel et al., 2004). The minimum infectious dose is so low that such practices like sharing a toothbrush or a razor blade can transmit infection (Chang, 2008). HBV and HCV share similar routes of transmission with HIV(Willey et al., 2008). These viruses have been detected in peripheral mononuclear cells, tissues of pancreas, spleen, kidney and skin fluids like saliva, semen, sweat, breast milk, tears, urine and vaginal secretion (Chen et al., 2009). Approximately 350 million people are infected with HBV worldwide (Liu and Hou, 2006).

Studies have shown that HCV and HBV account for substantial proportion of liver disease worldwide and infected individuals can remain asymptomatic for decades. However, more than $80 \%$ of them become chronic carriers which results in an increased risk of liver cirrhosis, hepatocellular carcinoma and liver failure 20-30 years later (Volf et al., 2008) and because they share similar modes of transmission, co-infection is uncommon especially among people at high risk for parenteral infection (Liu and Hou, 2006).

Epidemiological survey showed that about $5 \%$ of the world populations are asymptomatic carriers (Volf et al., 2008). Chronic HBV or HCV infection is the major cause of mortality among children and adults who might be HIV seronegative.

Studies in Nigeria have shown that HBV and HCV is the major aetiological factor for liver cirrhosis and hepatocellular carcinoma (Ojo et al., 2008). The prevalence rate of HIV infection in Nigeria has been on the increase because preventive measures have not had adequate impact from a prevalence rate of $1.4 \%$ in 1991 , it has increased to $5.8 \%$ by 2002 (Federal Ministry of Health report on HIV, 2002). Apart from the advantage of early detection and therapy initiation, this study is aimed at determining the seroprevalence rate of hepatitis B and C Co-Infection among HIV-1 infected patients at Federal Medical Center, Keffi, Nasarawa State, Nigeria. 


\section{Materials And Methods}

\section{Study Area and Population}

This study was conducted in Keffi, approximately $68 \mathrm{~km}$ from Abuja, the Federal Capital Territory and $128 \mathrm{~km}$ from Lafia, the Capital of Nasarawa state Keffi is located between latitude $8^{\circ} 5 \mathrm{~N}$ of the equator and longitude $7^{\circ} 8 \mathrm{E}$ and situated on an altitude of $850 \mathrm{~m}$ above sea level (Akwa et al., 2007).

The study participants were adults living with HIV / +AIDS and accessing health care at Federal Medical Center, Keffi. Written consent was obtained before subjects could participate in the study.

\section{Sample collection}

Blood samples were collected randomly from consenting study participants accessing care at the ART clinic of Federal Medical Center, Keffi. The blood samples (200) were collected by venipuncture method. The samples were processed and transferred into labeled plastic microtitre tube containing ethylene diamine tetraacetic acid (EDTA) and stored at $-20^{\circ} \mathrm{C}$ for use. The socio- demographic information of the participants was obtained by use of questionnaire.

\section{Laboratory Investigation}

The blood samples were centrifuged at 1500rpm for 15 minutes to separate the plasma from the blood. The plasma was then used for the screening of the HBsAg and HCV.

\section{Method of Screening for HBsAg and HCV}

All the patients were screened for HBV and HCV using rapid test kit (containing corresponding antigens) manufactured by ACON laboratories, USA. The test strip (one step) was a qualitative, lateral flow immunoassay for the detection of HBsAg and HCV in serum or plasma.

\section{Ethical Approval}

The study was conducted with the approval of the ethics review committee on health research, Federal Medical Centre, Keffi, Nasarawa State.

\section{Data and Statistical analysis}

The data gathered were analyzed using statistical package for social sciences (SPSS) version 17.0. Descriptive statistics were presented in bar charts and the Chi-square $\left(\mathrm{x}^{2}\right)$ test and was used to determine the level of association of the prevalence of HBV/HCV co-infection among HIV patients with respect to sex, age, marital status, occupation, HAART status and $\mathrm{CD}^{+} 4$ count. Values obtained were considered statistically significant at $\mathrm{p} \leq 0.05$.

\section{Interpretation Of Results}

\section{Results}

Of the $200 \mathrm{HIV}-1$ infected patients (54(27\%) males $156(73 \%)$ females) that participated in the study, $13.5 \%$ were HCV positive, $11 \%$ were HBV positive and $5 \%$ were dually co-infected. (Table 1 )

In relation to sex, this study reported the highest prevalence of co-infection among the male HIV patients with a recorded prevalence of $12.7 \%$ while the females had a low prevalence of $2.1 \%$. co-infection of HBV and HCV. This simply depicts that hepatitis B and C has no host preference as both sexes are susceptible to it. With respect to socio-demographic factor a higher infection rate $(5.5 \%)$ was documented among the rural dwellers while the urban settlers had the least infection rate (4.4\%). The lower class recorded a total prevalence of $34.7 \%$ while the upper class and middle class recorded a total prevalence of $25.3 \%$ and $20.5 \%$ respectively. This implies that the variation in the socio-economic status of the HIV patients has no influence on the prevalence rate of hepatitis.

Based on the patients educational status this study revealed the highest prevalence $(7.5 \%)$ of hepatitis B and C co-infection among patients that are uneducated because they are mostly not aware of the risk factors associated while the least prevalence was observed among the educated patients.

This study depicted the highest prevalence of hepatitis B and C co-infection among HIV patients with $\mathrm{CD}^{+} 4$ Count of $\leq 200$ with a recorded prevalence of (13.3\%) followed by patients with $\mathrm{CD}^{+} 4$ Count ranging from 201$300(7.3 \%)$ and $5 \%$ among patients with $\mathrm{CD}^{+} 4$ Count ranging from 401-500. The decrease in $\mathrm{CD}^{+} 4$ Count could be as a result of the presence the hepatitis viruses which are major contributors of early progression to AIDS in HIV patients thereby leading to death (Table 2).

Based on the ART status of the patients a higher prevalence was reported among patients on HAART with a recorded prevalence of $6.9 \%$ and $2.4 \%$ prevalence among HAART naïve patients (Table 3 ). 
The Seroprevalence Of Hepatitis B And C Virus Co-Infection Among Hiv-1infected Patients In Keffi,

Table 1. Socio-Demographic Characteristics and Seroprevalence Of Hepatitis B And C Co-Infection Among Patients.

\begin{tabular}{|c|c|c|c|c|c|c|c|c|}
\hline Characteristics & $\begin{array}{l}\text { Number } \\
\text { examined }\end{array}$ & $\begin{array}{l}\text { Number } \\
\text { reactive } \\
\mathrm{HCV} \\
(\%)\end{array}$ & P value & $\begin{array}{l}\text { Number } \\
\text { reactive } \\
\text { HBV } \\
(\%)\end{array}$ & Pvalue & $\begin{array}{l}\text { Number } \\
\text { reactive } \\
\text { HBV/HCV } \\
(\%)\end{array}$ & $\begin{array}{l}\text { Total } \\
\text { number } \\
\text { reactive } \\
(\%)\end{array}$ & P value \\
\hline $\begin{array}{l}\text { Age category } \\
\leq 20 \\
21-30 \\
31-40 \\
41-50 \\
51-60 \\
\geq 61\end{array}$ & $\begin{array}{l}12 \\
112 \\
55 \\
15 \\
6 \\
0\end{array}$ & $\begin{array}{l}2(16.6) \\
11(9.8) \\
8(14.5) \\
2(13.3) \\
3(50) \\
0(0)\end{array}$ & & $\begin{array}{l}2(16.6) \\
8(7.1) \\
8(14.5) \\
2(13.3) \\
2(33.3) \\
0(0)\end{array}$ & & $\begin{array}{l}1(8.3) \\
4(3.6) \\
3(5.5) \\
1(6.7) \\
1(25) \\
0(0)\end{array}$ & $\begin{array}{l}5(41.5) \\
23(20.5) \\
19(34.5) \\
5(33.3) \\
6(100) \\
0(0)\end{array}$ & $<0.05$ \\
\hline $\begin{array}{l}\text { Locality } \\
\text { Rural } \\
\text { Urban }\end{array}$ & $\begin{array}{l}110 \\
90\end{array}$ & $\begin{array}{l}14(10.7) \\
13(14)\end{array}$ & & $\begin{array}{l}12(10.9) \\
10(11)\end{array}$ & & $\begin{array}{l}6(5.5) \\
4(4.4)\end{array}$ & $\begin{array}{l}32(27.1) \\
27(29.4)\end{array}$ & \\
\hline $\begin{array}{l}\text { Gender } \\
\text { Male } \\
\text { Female }\end{array}$ & $\begin{array}{l}54 \\
146\end{array}$ & $\begin{array}{l}12(22.2) \\
15(10.3)\end{array}$ & & $\begin{array}{l}12(22.2) \\
10(6.8)\end{array}$ & & $\begin{array}{l}7(12.7) \\
3(2.1)\end{array}$ & $\begin{array}{l}29(57.1) \\
28(19.2)\end{array}$ & \\
\hline $\begin{array}{c}\text { Socio-economic } \\
\text { Lower class } \\
\text { Middle class } \\
\text { Upper class }\end{array}$ & $\begin{array}{l}90 \\
70 \\
40\end{array}$ & $\begin{array}{ll}15 & (14.7) \\
7 & (10) \\
5 & (10.5)\end{array}$ & & $\begin{array}{ll}12 & (13.3) \\
6 & (8.2) \\
4 & (10)\end{array}$ & & $\begin{array}{l}6(6.7) \\
2(2.1) \\
2(5)\end{array}$ & $\begin{array}{l}33(34.7) \\
15(20.3) \\
11(25.5)\end{array}$ & \\
\hline $\begin{array}{l}\text { Educational sta } \\
\text { Educated } \\
\text { Uneducated }\end{array}$ & $\begin{array}{l}80 \\
120\end{array}$ & $\begin{array}{l}10(12.5) \\
17(14.7)\end{array}$ & & $\begin{array}{l}8(10) \\
14(11.7)\end{array}$ & & $\begin{array}{l}4(5) \\
6(7.5)\end{array}$ & $\begin{array}{l}22(27.5) \\
37(30.8)\end{array}$ & \\
\hline $\begin{array}{l}\text { Occupation } \\
\text { Civil servant } \\
\text { Students } \\
\text { Farmers } \\
\text { Artisans } \\
\text { Unemployed }\end{array}$ & $\begin{array}{l}40 \\
35 \\
28 \\
38 \\
59\end{array}$ & $\begin{array}{l}8(20) \\
6(17) \\
4(14.3) \\
4(10.5) \\
5(8.5)\end{array}$ & $\leq 0.05$ & $\begin{array}{l}4(10) \\
5(14.3) \\
4(14.3) \\
4(10.5) \\
5(8.5)\end{array}$ & $<0.05$ & $\begin{array}{l}0(0) \\
4(11.4) \\
2(7.1) \\
2(5.3) \\
2(3.4)\end{array}$ & $\begin{array}{l}12(30) \\
15(42.7) \\
10(35.7) \\
10(26.3) \\
12(20.4)\end{array}$ & \\
\hline $\begin{array}{l}\text { Marital status } \\
\text { Single } \\
\text { Married } \\
\text { Divorced }\end{array}$ & $\begin{array}{l}64 \\
118 \\
18\end{array}$ & $\begin{array}{l}9(14.1) \\
16(13.6) \\
2(11.1)\end{array}$ & & $\begin{array}{l}6(9.4) \\
10(8.5) \\
6(33.3)\end{array}$ & & $\begin{array}{l}6(9.4) \\
4(3.4) \\
0(0)\end{array}$ & $\begin{array}{l}21(25) \\
30(17.5) \\
8(44.4)\end{array}$ & \\
\hline
\end{tabular}

Table 2 The Seroprevalence Of Hepatitis B And C Co-Infection Among Hiv Patients In Relation To Cd ${ }^{+}$

\begin{tabular}{|c|c|c|c|c|c|c|c|}
\hline $\mathrm{Cd}^{+} 4$ Count & $\begin{array}{l}\text { Number } \\
\text { Examined }\end{array}$ & $\begin{array}{l}\text { Number } \\
\text { Reactive } \\
(\%)\end{array}$ & Hev & $\begin{array}{l}\text { Number } \\
\text { Reactive } \\
(\%)\end{array}$ & Hbv & $\begin{array}{l}\text { Number } \\
\text { Reactive } \\
\text { Hbv/Hev (\%) }\end{array}$ & $\begin{array}{l}\text { Total Number } \\
\text { Reactive }(\%)\end{array}$ \\
\hline$\leq \mathbf{2 0 0}$ & 30 & $8(26.7)$ & & $7(33.3)$ & & $4(13.3)$ & $19(63.3)$ \\
\hline 201-300 & 55 & $11(20)$ & & $6(10.9)$ & & $4(7.3)$ & $21(38.2)$ \\
\hline $301-400$ & 42 & $11(26.2)$ & & $1(2.4)$ & & $0(0)$ & $12(28.6)$ \\
\hline 401-500 & 40 & $4(10)$ & & $4(10)$ & & $2(5)$ & $10(25)$ \\
\hline 501-600 & 14 & $1(7.1)$ & & $2(14.3)$ & & $0(0)$ & $3(21.4)$ \\
\hline$\geq 600$ & 19 & $2(10.5)$ & & $2(10.5)$ & & $0(0)$ & $4(21)$ \\
\hline Total & 200 & $27(13.5)$ & & $22(11)$ & & $10(5)$ & $59(29.5)$ \\
\hline
\end{tabular}

Table 3: The Seroprevalence Of Hepatitis B And C Co-Infection Among Hiv Patients In Relation To Art Status.

\begin{tabular}{llllll}
\hline Art Status & Number Examined & $\begin{array}{l}\text { Number React } \\
\text { Ve Hev (\%) }\end{array}$ & $\begin{array}{l}\text { Number Reactive } \\
\text { Hbv (\%) }\end{array}$ & $\begin{array}{l}\text { Number } \\
\text { Hbv/Hev (\%) }\end{array}$ & $\begin{array}{l}\text { Reactive } \\
\text { Total } \\
\text { Reactive (\%) }\end{array}$ \\
\hline On Haart & 115 & $20(17.4)$ & $14(12.2)$ & $8(6.9)$ & $42(36.2)$ \\
Haart Naïve & 85 & $7(8.2)$ & $8(9.4)$ & $2(2.4)$ & $17(20)$ \\
Total & 200 & $27(13.5)$ & $22(11)$ & $10(5)$ & $59(29.5)$ \\
\hline
\end{tabular}




\section{Discussion}

This study examined the seroprevalence of HBV and HCV co-infection among HIV patients and the observed positivity of HBV, HCV and co-infection obtained was $22(11 \%), 27(13.5 \%)$ and $10(5 \%)$ respectively. The prevalence rates of HBV and HCV among these patients are comparable with reports by (Forbi et al., 2007), in north central Nigeria, (Ameh et al, 2012) in North East of Nigeria, South African cohort (Parboosing et al., 2008), Senegal (Diop-Ndaiye et al., 2008) and France (Larsen et al,. 2008). The prevalence rates of HBV obtained in this study is not comparable with previous reported high prevalence in different part of Nigeria; Keffi (20.6\%) (Forbi et al., 2007), Jos (28.7\%) (Irisena et al., 2002), Illorin (30.4\%) (Olatunji et al., 2008), Kano (70.5\%) (Nwokedi et al., 2006) and India (33.8\%) (Stud et al., 2001). Some other studies reported a prevalence of 6\% from South Africa (lodenyo et al., 2000) and Nigeria; Maiduguri 15\% (Baba et al., 1998), Lagos 9.2\% (Lesi et al., 2007), Niger- Delta (9.7\%) (Ejele et al., 2004), and Thailand 8.7\% (Sunkanuparph., 2004) which are however comparable with observed figures in this study (11\%). In Brazil, the results of a study showed that the rates of prevalence of HBV/HCV co-infection among HIV patients is $5 \%$ (Tripathi et al., 2007) which is the same with the result obtained in this study. In the US and Europe HBV/HCV co-infection among HIV patients was reported to be within the range of 6-14\% (Dodig et al., 2001). In a similar study carried out in Alivaz -South Iran, the co-infection rates of HBV/HCV in HIV patients was found to be $20 \%$ (Alavi et al., 2007) which is higher than the rate obtained in this study. In another study conducted in Nigeria HBV/HCV coinfection rates was found to be less than $1 \%$ (Otegbayo et al., 2008) which is not comparable with the coinfection rate obtained in this study.

Analysis of the sex-related sero-prevalence of HBV/HCV co-infection amongst the HIV infected patients showed that the males $(12.7 \%)$ were more infected than the females $(2.1 \%)$, though more of the female patients reported to hospital for medical attention than the males. The reason for higher frequency of HBV/HCV coinfection among the male patients could probably be as a result of higher frequency of exposure to risk factors associated with the viruses such as injection of drug use, unprotected sex and having more than one sex partners as well as occupation and behaviour (Halim et al., 1992). However statistically significant association was observed among patients in respect to sex $(\mathrm{p} \leq 0.05)$ which is comparable to results reported by (Halim et al.,1992). This observation is not at par with previous study by (Lesi et al., 2007) who reported a higher prevalence among the female patients $(37.5 \%)$ than the male patients $(18.8 \%)$

The present study has reported a higher prevalence of Hepatitis B and C co-infection among patients of age $<20$ and $>40$ years with a reported prevalence of $8.3 \%$ and $25 \%$ and a higher prevalence of hepatitis B alone among patients of age $<20(16.6 \%)$ and $>40(33.3 \%)$ years and $\mathrm{HCV}$ alone among patients of age 51-60 years. Although there was no statistically significant difference between the prevalence of the hepatitis viruses in respect to age ( $>>0.05)$ which is comparable with the study carried out by (Mohsen et al.,2009) who reported a prevalence of $77.2 \%$ among patients aged $<30$ infected with $\mathrm{HCV}$ alone and $74.2 \%$ among patients aged $31-50$ and a prevalence of 12.9 among patients infected with $\mathrm{HBV}$ alone of aged $<30$ and $13.2 \%$ in patients aged $>40$ years and finally $\mathrm{HBV} / \mathrm{HCV}$ coinfection rates of $5.7 \%$ and $8.9 \%$ in the age group of HIV positive patients $<40$ and $>60$ years.

Analysis of marital status-related sero-prevalence of HBV/HCV co-infection amongst the HIV infected patients showed that there was a higher prevalence of the viruses among patients that are single $(9.4 \%)$ compared to those that are married $(3.4 \%)$ and divorced $(0 \%)$ which could probably be due to high tendency of promiscuous behavior among those who are single than those that are married. However, the difference was not statistically significant ( $>0.05$ ) which is comparable to study conducted by (Mohsen et al., 2009).

There was no statistically significant association found in this study between $\mathrm{CD}^{+} 4$ Count and serological status of the subjects. As shown in the present study individuals with the highest prevalence of HBV/HCV co-infection are having $\mathrm{CD}^{+} 4$ Count less than 200 which depicts that decrease in $\mathrm{CD}^{+} 4$ Count among HIV patients could be attributed to co-infection with either of viral hepatitis or even both. This finding is comparable with a finding observed in a previous work in Jos, Nigeria (Ladep et al., 2007). Although, the reasons for the $\mathrm{CD}^{+} 4$ Count decline is not clear but it is known that there is an in-balance in peripheral blood T-lymphocytes subsets and turbulence in cellular immunity in the patients with chronic hepatitis infections (Tian et al., 2005).

The higher prevalence rate of HCV in HIV patients in comparison to the rate for HBV in HIV patients could be considered as noticeable and it could be attributed to diverse factors particularly lack of vaccines for HCV contrary to the existence of vaccines for HBV. Also, sexual transmission of this virus is lower in comparison to HBV and it is transmitted mostly via infection especially in drug addiction (Alter, 2002). Many studies have been conducted in this realm, all showing high rates for the viruses in HIV patients due to the above mentioned factors. Some patients are currently infected with the three viruses of HIV, HBV and HCV due to their shared risk factors and mode of transmission. Consequently, co-infection with the three viruses will increases the risk of cirrhosis, liver deficiency, and mortalities in comparison to when a person is infected with only one of these viruses. Therefore, diagnosing HBV/HCV in HIV patients is vital order to take care of them and allot resources 
in health plans so that all HIV patients have to be tested for both HBV and HCV (Salmon et al., 2003 and Bruno $., 2007)$

\section{Conclusion}

With the $5 \%$ prevalence of $\mathrm{HBV} / \mathrm{HCV}$ co-infection in this study population, it is an indication that HBV and $\mathrm{HCV}$ infection are on the increase in HIV patients which are the major contributor to increase in morbidity and mortality among these patients as a result of rapid progression to AIDS and hepatocellular carcinoma. This study has provided evidence that HBV/HCV co-infection among HIV patients may not be common among these patients. While the small sample size of the study population is acknowledge and a more elaborate study, especially multi-center studies should be conducted to determine the national prevalence of $\mathrm{HBV} / \mathrm{HCV}$ coinfection to enable the formulation of guidelines for management and establishment of preventive programs.

\section{References}

[1]. Akwa, V.L., Binbol, N.L., Samaila, K.L., and Marcus, N.D., (2007). Geographical Perspective of Nasarawa State. Onaiv Printing and Publishing Company, Keffi. pp 3

[2]. Alavi S.M, Etemadi A, (2007).HIV/HBV, HIV/HCV and HIV/HLTV Co-infections among injection drug-users patients hospitalized at the infectious disease ward of training hospital in Iran. Park J. Med. Sci: 23: 510-13

[3]. Ameh James, Joseph Okwori, Humphrey Musuluma, Henry Mbah (2012) Hepatitis B and C co-infection among HIV-1 positive individuals in the North-East of Nigeria: prevalence and implication of high risk sexual behaviour in the transmission of hepatitis C virus. Journal of Medicine and Medical Science Vol. 3(12) pp. 784-788. Available online http://www.interesiournals.org/JMMS

[4]. Baba M.M, Gashau W, Hassan A.W (1998). Detection of HBsAg in patient's mirth and 'without the manifestations of AIDS in Maiduguri; Nigeria, Niger postgrad. Med. J., 5: 125-8 Disease. Official Journal of the Italian Society of Gastroenterology and the Italian Association for the study of the Liver. 43(1): S57-63

[5]. Chang, M.H. (2008): Hepatitis B Virus Infection; Neonatal Medicine. 12: 160-167.

[6]. Chen, L., Lin, F., Fan, X., Gao, J., Chen, N., Wong, T., Wu, J., Wenz, S.W., (2009): Detection of Hepatitis B Surface Antigen, Hepatitis C Cure Antigen and Hepatitis B Virus DNA in Paratoid Tissues. International Journal of Infectious Diseases.13: $20-23$.

[7]. Diop-Ndiaye H, Toure-Kane C, Etard J.F, Lo G, Diaw p, Ngom-Gueye N.F, Gueye P.M, (2008). Hepatitis B, C seroprevalence and delta viruses in HIV -1 Senegalese patients at Haart initiation. J. Med Virology: 80:1332-1336

[9]. Dodig, M., Tarill, A.S. (2001): Hepatitis and HIV Infections. Journal of Gastroenterol. 33: 367-374

[10]. Ejele, O.A., Erhabor, O., and Nwauche, C.A. (2005): The Risk of Transfusion- Transmission Infection in the Niger-Delta Area of Nigeria. Sahel Medical Journal. 8: 16-19.

[11]. Federal Ministry of health, Department of Public Health (2004): National AIDS Control Programme. Technical Report: 2003 National HIV Seroprevalence Sentinel Survey.

[12]. Forbi F.C, Gabadi S, Alabi R (2007). The role of triple infection with hepatitis B virus, hepatitis C virus and Human immunodeficiency virus (HIV) type 1 on CD4 lymphocytes levels in the highly infected population of north central Nigeria. Mem inst. Oswalso cruz; 102: 535-537

[13]. Halim M.D, Offor E, Ajayi O.I (1992). Epidemiologic study of the seroprevalence of hepatitis B surface Antigen and HIV-1 in blood donors. Niger. J. Clin. Pract.: 2; 45-55

[14] Irisena N.D, Njoku M.D, Idoko J.A (2002).HBsAg in patients with HIV-1 infection in Jos, Nigeria. Nig. Med. Pract. 41 (12): $18-20$

[15]. Ladep N.G, Agbaji O, Agaba P, Badung P, Imade G, Sankale J, Idoko J, Kanki P (2007). Effects of Hepatitis C prevalence on the immunological status of HIV infected patients. Niger J. Med: 16; 231-234

[16]. Lesi O.A, Kehinde M.O, Oguh, D.N, Amira C.O (2007). Hepatitis B and C Virus infections in Nigerian patients with HIV /AIDS. Niger postgrad Medical Journal: 14: 129-133

[17]. Liu, Z., Hou, J (2006): Hepatitis B Virus and Hepatitis C Virus Dual Infection. International Journal of Medical Sciences. 3: 5762.

[18]. Lodenyo H, Schoub B, Ailly R, Kairu S, Segel I (2000). Hepatitis B and C virus infections and liver function in AIDS patients at Hani Baragwanath Hospital, Johannesburg. East Africa Med Journal, 77;13-15

[19]. Mohsen, A.H., Easterbrook, P., Taylor, C.B., Norris, S., (2002): hepatitis C and HIV-1 Co-infection. Journal of Clinical Infectious Diseases. 51: 601-608.

[20]. Monga, H.K., Rodrigues - Barrades, U.C., Breaux, K., Khattak, K., Troisi, C.L., Velez, M., Yoffe, B. (2001): Hepatitis C Virus Infection Related Morbidity and Mortality among Patients with Human Immunodeficiency Virus Infection. Journal of Clinical Infectious Disease. 33: 240-247.

[21]. Nwokedi, E. E, Epopees M.A, Dutse, A.I (2006). Human Immunodeficiency Virus and Hepatitis B virus co-infection among patients in kano, Nigeria. Niger. J. Med. 15 (3): 227-9

[22]. Ojo, O.S., Akanni, A.K., Thursaz, M., Ndububa, D.A., Dmosinmi, M.A., Adeodu, O.O., (2008): Hepatitis C and Hepatitis B Virus Antibodies in Nigerian Patients with HIV. East African Medical Journal, 75(6): 329-31.

[23]. Olatunji P.O, Iseniyi, J.O (2008). Hepatitis B and C virus Co-infection with human immunodeficiency Virus infected patients at UITH Nigerian Medical Practitioner Journal: 54; 8-10.

[24]. Otegbayo J.A. Babafemi, T.O, Akingbayo, T.S (2008). Prevalence of hepatitis B and C seropositivity in a Nigerian cohort of HIV infected patients. Ann Hepatol; 152-15

[25]. Parboosing R, Parauk I, Lalloo U.G, (2008). Hepatitis C seropositivity in a south African Cohort of HIV infected, ARV naïve patients is associated with renal insufficiency and increased mortality. J Med. Virology: 80 (9);1530-6

[26]. Punpapong, S., Kim, W.R., Poterucha, J.J. (2007): National History of Hepatitis B Virus Infection: An Update for Clinicians. Major Clinical Produce. 82: 967-975.

[27]. Salmon-ceron D, Gouezel P, Delaroque- Astagneau E, Piroth L, Dellamonica P, marcellin P (2003) Co-infection HIV-HCV at hospital in French. French Medical Journal. (33): 78-83

[28]. Samuel, D., Mullar, R., and Alexander, G. (2004): Educational Research, National Hepatitis B Virus programmes. Infectious Diseases Journal. 234-332. 
[29]. Stud A, Singh J, Dhiman R.K, Wanchu A, Singh S, Chawia Y. (2001) Hepatitis B infection in HIV patients.Trop Gastroenterol J. 22(2), $90-92$

[30]. SungKamuparph, S., Vihagool, A., Manosathi, W., Kiertiburanakul, S., Atamasirikul, $\quad$ K (2004): Prevalence of Hepatitis B Virus and Hepatitis C Virus Co-infection with Human Immunodeficiency Virus in Thai Patients: A tertiary-Based Study: Journal of Medical Associates, Thai. 87: 1349-54.

[31]. Tian P.C (2005). Management and treatment of Hepatitis C virus infection in HIV-Infected adults: recommendation from the veterans' affairs Hepatitis C Resources Center program and national Hepatitis C program office. Am. J. Gasterolo. 100; 2338-2354

[32]. Tripathi A.K, Khanna M, Gupta N, Chandra M (2007). Low prevalence of Hepatitis B Virus and Hepatitis C Virus Coinfection in patients with HIV in Northern India. JAPI: $\quad$ 55: 429-31

[33]. UNAIDS (2005): HIV Epidemic Update Geneva; UNAIDS.

[34]. UNAIDS/WHO (2002): HIV Epidemic Update Geneva.

[35]. Volf, V., Marx, D., Pliscora, L. Sumega, L. Celko, A., (2008): A Survey of Hepatitis B Community of Paragues. European Journal of Public health. 18-44.

[36]. Willey, J.M., Sherwood, L.M., Woolverton, C.J (2008): Prescott, Harley and Klein $\quad$ Microbiology (4 ${ }^{\text {th }}$ Edition): McGraw Hill Publishers, New York Press: 936-972. 